Gut, 1973, 14, 723-725

\title{
Serum immunoglobulins in calcific pancreatitis ${ }^{1}$
}

\author{
SIMMY BANK, B. H. NOVIS, E. PETERSEN, E. DOWDLE, AND I. N. MARKS \\ From the Gastrointestinal Clinic, Groote Schuur Hospital, Observatory, Cape Town, and the Departments of \\ Medicine and Clinical Science, University of Cape Town, Cape Town, South Africa
}

SUMMARY Serum immunoglobulin concentrations were measured in 40 patients with calcific pancreatitis. A significant elevation of the mean serum IgA and IgG concentration when compared with a control group was found. The IgA was raised in $50 \%$ and the IgG in $27.5 \%$ when the individual results were assessed. The IgA did not appear to be of the secretory type.

The possible significance of the raised IgA and IgG is discussed with reference to local pancreatic IgA production, autoimmune factors in chronic pancreatitis, and the ductal protein plugs in this disease.

Serum immunoglobulin levels have been studied in a variety of gastrointestinal diseases. High serum IgA values occur in patients with untreated coeliac disease, ulcerative colitis, and Crohn's disease (Asquith, Thompson, Cooke, 1969; Kraft, Ford, McCleery, and Kirsner, 1968) and high IgG and IgA levels have been recorded in hepatic cirrhosis and high IgM in biliary cirrhosis (McKelvey and Fahey, 1965; Osserman and Takatsuki, 1963; Feizi, 1968). Immunoglobulins in the serum have been studied in fibrocystic disease (Schwartz, 1966) and pancreatic juice immunoglobulins reported in "calcifying pancreatitis' (Clemente, Ribeiro, Colomb, Figarella, and Sarles, 1971). To our knowledge there are no studies on serum immunoglobulin values in adults with pancreatitis.

The present paper reports on the serum immunoglobulins-IgG, $\operatorname{IgA}$, and $\operatorname{IgM}$-in a group of patients with calcific pancreatitis. The results indicate that many of these patients have elevated serum concentrations of $\operatorname{IgA}$ and $\operatorname{IgG}$, while IgM levels were normal.

\section{Material}

Forty patients with radiological calcification of the pancreas and a grossly abnormal secretin/cholecystokinin pancreatic function test (Bank, Marks, Lurie, Novis, and Barbezat, 1972) were investigated. The pancreatitis was alcohol-induced in 38 and in the remaining two no aetiology could be established.

'This study was supported by the Medical Research Council of South Africa.

Received for publication 11 June 1973.
Twenty-nine had overt diabetes and 12 had clinical and biochemical steatorrhoea. None of the patients had clinical or biochemical evidence of liver disease and the liver was macroscopically normal in seven patients operated on for their pancreatic disease in the preceding few years. All the patients were investigated in the interval between acute attacks and only one, with abdominal tuberculosis, had evidence of extrapancreatic chronic inflammatory disease. None showed any stigmata of fibrocystic disease.

Thirty-four healthy volunteers, matched for age, sex, and race, served as controls.

\section{Methods}

Serum was separated from blood taken by venesection and stored at $-20^{\circ} \mathrm{C}$. Immunoglobulin levels were measured by the single radial immunodiffusion method (Mancini, Carbonera, and Heremans, 1965) on commercially available agar plates containing monospecific anti-immunoglobulin antiserum (Tri-partigen, Behringwerke, West Germany) using a standard curve constructed from dilutions of accurately calibrated standard serum (Behringwerke).

To exclude qualitative immunoglobulin abnormalities, immunoelectrophoresis was carried out on all sera on agarose gel plates using monospecific rabbit antisera against human IgG, IgA, and $\mathrm{K}$ and L light chains (Behringwerke).

In three of the cases with serum IgA levels greater than $500 \mathrm{mg} / 100 \mathrm{ml}$ an attempt was made to establish the presence of an $11 \mathrm{~S}$ peak characteristic of secretory IgA. The sera were diluted 1 in 3 with $0.15 \mathrm{M}$ $\mathrm{NaCl}$ and spun at $240000 \mathrm{~g}$ for 90 minutes on an 


\begin{tabular}{|c|c|c|c|c|c|}
\hline & \multicolumn{2}{|l|}{ Controls } & \multicolumn{2}{|l|}{ Patients } & \multirow[t]{2}{*}{ Significance $^{1}$} \\
\hline & Range $(\mathrm{mg} / 100 \mathrm{ml})$ & $M e a n \pm S D(m g / 100 m l)$ & Range $(\mathrm{mg} / 100 \mathrm{ml})$ & Mean $\pm S D(m g / 100 m l)$ & \\
\hline $\begin{array}{l}\text { IgG } \\
\text { IgA } \\
\text { IgM }\end{array}$ & $\begin{array}{c}230-1540 \\
68-350 \\
54-280\end{array}$ & $\begin{array}{r}1026 \pm 257 \\
171 \pm 69 \\
129 \pm 51\end{array}$ & $\begin{array}{c}675-2300 \\
117-876 \\
54-231\end{array}$ & $\begin{aligned} 1362 & \pm 412 \\
357 & \pm 168 \\
122 & \pm 46\end{aligned}$ & $\begin{array}{l}P<0.0005 \\
P<0.0005 \\
P>0.25\end{array}$ \\
\hline
\end{tabular}

Table Comparison of serum immunoglobulins in patients and controls

${ }^{1}$ Student $t$ and Mann-Whitney analysis

analytical ultracentrifuge (Beckman model E). Two single sector cells were used.

\section{Results}

As can be seen from the data summarized in the table, patients with calcific pancreatitis had significantly elevated mean serum concentrations of IgG $(P<0.0005)$ and $\operatorname{IgA}(P<0.0005)$. The mean serum concentration of IgM did not differ significantly between the two groups.

The figure shows the individual results for controls and patients. None of the controls had an IgG greater than $1600 \mathrm{mg} \%$ (the accepted upper limit of normal) while among the patient group $27.5 \%$ exceeded this level and $12.5 \%$ had a value greater than $2000 \mathrm{mg} \%$. One clinically well control had a rather low IgG level of $235 \mathrm{mg} \%$. The highest IgA value in the controls was $350 \mathrm{mg} \%$ and no fewer than $50 \%$ of the patient group had values greater than this while $22.5 \%$ had levels exceeding $500 \mathrm{mg} \%$. There was little difference in IgM values in the two groups.

On serum immunoelectrophoresis, the IgG, IgA, and IgM precipitin lines were qualitatively normal in all 40 patients and the reaction to light chain antisera was always normal.

Analytical ultracentrifugation of three serum samples with IgA levels higher than $500 \mathrm{mg} \%$ failed to reveal any evidence of an $11 \mathrm{~S}$ component, indicat-
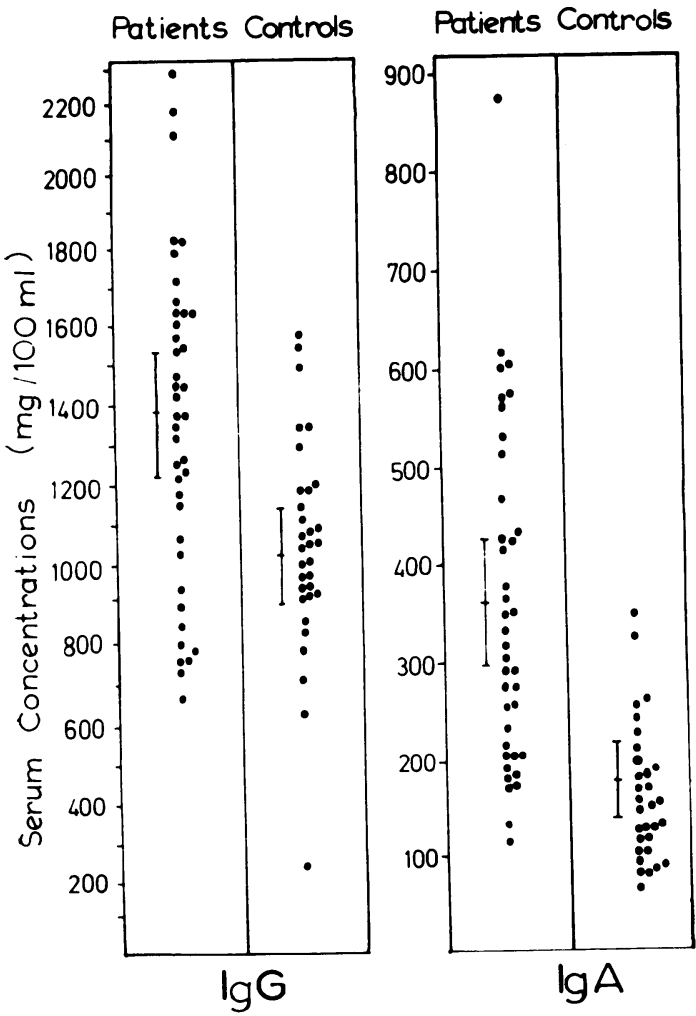

Patients Controls

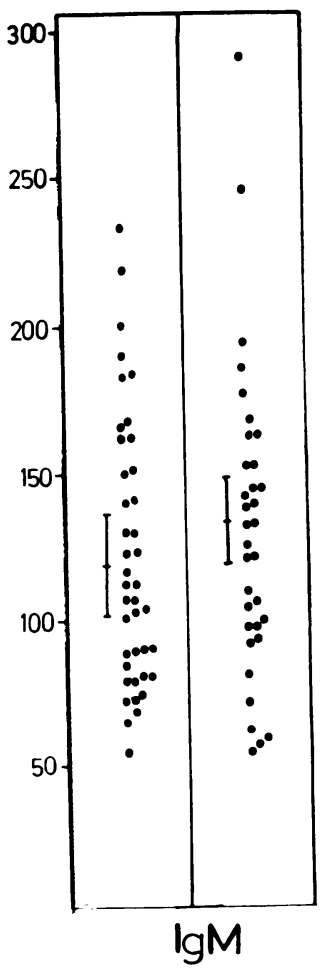

Fig Individual immunoglobulin levels in 40 patients with calcific pancreatitis and control subjects. 
ing that, in these three cases, there was no substantial contribution by secretory $\operatorname{IgA}$ to the raised levels encountered.

\section{Discussion}

The results of this study show that serum IgA and IgG concentrations are elevated in a proportion of patients with calcific pancreatitis. The serum IgM did not differ significantly from the control group. The immunoglobulin pattern was normal on immunoelectrophoresis in all patients. The serum IgA was elevated in $50 \%$ and the serum IgG in about a quarter of the patients. The raised immunoglobulin levels appeared to be related to the pancreatic disease and not to the presence of extrapancreatic infection, activity of the disease, or the presence of pancreatic diabetes or steatorrhoea. Similar elevations in $\operatorname{IgA}$ and $\operatorname{IgG}$ have been recorded in hepatic cirrhosis but none of the patients in the present series had clinical or biochemical evidence of cirrhosis or hepatic dysfunction. It has also previously been shown that hyperglobulinaemia is not uncommon but cirrhosis relatively unusual in patients with alcohol-induced pancreatitis (Bank, Marks, and Bock, 1967; Sarles and GerolamiSantandrea, 1972). Raised immunoglobulin levels have been shown to occur in fibrocystic disease of the pancreas but in the latter disease the presence of pulmonary infection may contribute to the raised IgG and IgA (Schwartz, 1966). Although there were no stigmata of fibrocystic disease in the 40 adult patients investigated in the present series, a basic genetic disorder rendering the pancreas particularly liable to the injurious effects of alcohol cannot be entirely dismissed.

The pathogenesis and significance of the raised IgA and IgG levels in calcific pancreatitis is uncertain. Clemente et al (1971) have demonstrated an excess of serum protein in the pancreatic juice of patients with 'calcifying pancreatitis' and, on the basis of the relative proportions of albumin and $\operatorname{IgA}$ present, suggested the local synthesis of IgA by plasma cells in close anatomical relationship to the mucous membrane of the pancreatic duct. This suggestion is consistent, by analogy, with the fact that IgA is the predominant immunoglobulin in other external secretions such as saliva, tears, intestinal secretion, and bile (Tomasi, 1972; Jones, 1972). The IgA responsible for the elevated serum levels is thus probably of pancreatic origin.

It is conceivable that the elevated IgA and IgG levels reflect, in a poorly understood, 'non-specific' manner, the presence of chronic inflammation in the pancreas. In this regard it is of interest that patients with chronic pancreatitis in South Africa (Uys, Bank, and Marks, 1973, unpublished data) tended to show more chronic inflammatory cell infiltration of the plasma and lymphocyte type. These cells may be the source of the elevated immunoglobulins. Although pancreatic isoantibodies were demonstrated in chronic pancreatitis by Murray and Thal as early as 1960 there is as yet little to suggest that autoimmunity plays any major part in the pathogenesis of the disease. However the high immunoglobulin levels may be related to autoimmune processes in the pancreas once the disease is established and may contribute to the progressive nature of the disease despite alcohol withdrawal or cessation of attacks.

Whether immunoglobulins are incorporated into the ductal protein plugs (Sarles, Lebreuil, Tasso, Figarella, Clemente, Devaux, Fagonde, and Payan, 1971) characteristically seen in 'calcifying pancreatitis' is unknown. The absence of $11 \mathrm{~S}$ IgA in three patients with high $\operatorname{IgA}$ values may reflect deficient synthesis of the secretory component by the diseased ductal epithelium with resultant accumulation and back-diffusion of monomeric IgA (Tomasi, 1972).

\section{References}

Asquith, P., Thompson, R. A., and Cooke, W. T. (1969). Serumimmunoglobulins in adult coeliac disease. Lancet, 2, 129-131.

Bank, S., Marks, I. N., and Bock, O. A. A. (1967). Gastric, intestinal and hepatic function in pancreatitis. Recent Advanc. Gastroent., 4, 412-415.

Bank, S., Marks, I. N., Lurie, B., Novis, B. H., and Barbezat, G. O. (1972). Precalcific pancreatitis. S. Afr. med. J., 46, 2093-2097.

Clemente, F., Ribeiro, T., Colomb, E., Figarella, C., and Sarles, $\dot{H}$. (1971). Comparison des proteins de sucs pancreatiques humains normaux et pathologiques. Dosage des proteines seriques et mise en evidence d'une proteine particuliere dans la pancreatite chronique calcifiante. Biochem. biophys. Acta (Amst.) 251, 456-466.

Feizi, T. (1968). Immunoglobulins in chronic liver disease. Gut, 13, 825-835.

Jones, E. A. (1972). Immunoglobulins and the gut. Gut, 13, 825835.

Kraft, S. C., Ford, H. E., McCleery, J. L., and Kirsner, J. B. (1968) Serum immunoglobulin levels in ulcerative colitis and Crohn's disease (Abstr.). Gastroenterology, 54, 1251.

Mancini, G., Carbonera, A. O., and Heremans, J. F. (1965). Immunochemical quantitation of antigens by single radial immunodiffusion. Immunochemistry, 2, 235-254.

McKelvey, E. M., and Fahey, J. L. (1965). Immunoglobulin changes in disease. $J$. clin. Invest., 44, 1778-1787.

Murray, M. J., and Thal, A. P. (1960). Clinical significance of circulating pancreatic antibodies. Ann. intern. Med., 53, 548-555.

Osserman, E. F., and Takatsuki, K. (1963). The plasma proteins in liver disease. Med. Clin. N. Amer., 47, 679-710.

Sarles, H., and Gerolami-Santandrea, A. (1972). Chronic pancreatitis. Clin. Gastroent., 1, 167-193.

Sarles, H., Lebreuil, G., Tasso, F., Figarella, C., Clemente, F., Devaux, M. A., Fagonde, B., and Payan, H. (1971). A comparison of alcoholic pancreatitis in rat and man. Gut, 12,
377-388.

Schwartz, R. H. (1966). Serum immunoglobulin levels in cystic fibrosis. Amer. J. Dis. Child., 111, 408-411.

Tomasi, T. B., Jr. (1972). Secretory immunoglobulins. New Engl. J. 